\title{
The Development and Historic Use of Habitat Structures in Channel Restoration in the United States: The Grand Experiment in Fisheries Management Le développement et l'histoire des structures destinées à l'habitat aquatique dans les cours d'eau aux États-Unis : un essai de gestion des populations de poissons
}

\author{
Douglas M. Thompson et Gregory N. Stull
}

Volume 56, numéro 1, 2002

URI : https://id.erudit.org/iderudit/008604ar

DOI : https://doi.org/10.7202/008604ar

\section{Aller au sommaire du numéro}

\section{Éditeur(s)}

Les Presses de l'Université de Montréal

ISSN

0705-7199 (imprimé)

1492-143X (numérique)

Découvrir la revue

Citer cet article

Thompson, D. M. \& Stull, G. N. (2002). The Development and Historic Use of Habitat Structures in Channel Restoration in the United States: The Grand Experiment in Fisheries Management. Géographie physique et Quaternaire, 56(1), 45-60. https://doi.org/10.7202/008604ar

\section{Résumé de l'article}

L'emploi de structures aménagées dans le lit des rivières visant à modifier l'habitat aquatique a une longue histoire aux États-Unis. Des travaux pionniers effectués par de riches propriétaires terriens dans la région des Catskills (État de New York) ont entraîné l'élaboration d'un éventail de designs durant les décennies qui ont précédé la Grande Dépression ; ceux-ci visaient le rétablissement des populations de poissons lourdement touchées par une pêche excessive. L'évaluation scientifique de ces structures a débuté en 1930. En moins de deux ans, une équipe de recherche du Michigan a déclaré avoir obtenu un accroissement des populations de poissons. Dans les années 1930, une main-d'oeuvre bon marché et des projets de conservation subventionnés par le gouvernement et supervisés par le Civilian Conservation Corps ont concouru à étendre à grande échelle l'emploi des techniques du Michigan et ce, avant même qu'une évaluation adéquate des effets à long terme de tels dispositifs ne soit complétée. Le début de la Seconde Guerre mondiale a temporairement interrompu les efforts de conservation gouvernementaux et a empêché l'évaluation suivie des structures en place. Durant les années 1940, 1950 et 1960, le design de ce type de structures est demeuré pratiquement inchangé et les quelques recherches réalisées pour évaluer leur impact se sont souvent révélées erronées. L’usage continu de ces dispositifs primitifs a contribué à corroborer la fausse croyance selon laquelle leur effet bénéfique sur les poissons était démontré. Même maintenant, l'utilisation de ces structures aménagées dans les cours d'eau continue à reposer sur les plans rudimentaires élaborés autrefois dans les Catskills, malgré les problèmes relatés dans la littérature quant à leur emploi. 


\section{THE DEVELOPMENT AND HISTORIC USE OF HABITAT STRUCTURES IN CHANNEL RESTORATION IN THE UNITED STATES: THE GRAND EXPERIMENT IN FISHERIES MANAGEMENT}

Douglas M. THOMPSON* and Gregory N. STULL, Department of Physics, Astronomy and Geophysics, Connecticut College, Campus Box 5585, 270 Mohegan Avenue, New London, Connecticut 06320, U.S.A.

ABSTRACT The use of instream structures to modify aquatic habitat has a long history in the United States. Pioneering work by wealthy landowners in the Catskills region of New York produced a range of designs in the decades preceding the Great Depression in an effort to replenish fish populations depleted from overfishing. The scientific evaluation of structures began in 1930. Within two years, a Michigan research team claimed improved fish populations. Cheap labor and government-sponsored conservation projects spearheaded by the Civilian Conservation Corps allowed the widespread adoption of the techniques in the 1930s, before adequate testing of the long-term impact of the devices. The start of World War II temporarily ended the government conservation efforts and prevented the continued evaluation of structures. During the 1940s, 1950s and 1960s, designs of instream structures remained essentially unchanged. Meanwhile, the small number of evaluations of the impact of the structures often were flawed. The continued use of early designs of instream structures helped instill a false belief that instream structures were proven to be a benefit to fish. Even modern use of instream structures continues to rely on the basic blueprints developed in the Catskills, despite documented problems with the use of these designs.
RÉSUMÉ Le développement et l'histoire des structures destinées à l'habitat aquatique dans les cours d'eau aux États-Unis : un essai de gestion des populations de poissons. L'emploi de structures aménagées dans le lit des rivières visant à modifier l'habitat aquatique a une longue histoire aux ÉtatsUnis. Des travaux pionniers effectués par de riches propriétaires terriens dans la région des Catskills (État de New York) ont entraîné l'élaboration d'un éventail de designs durant les décennies qui ont précédé la Grande Dépression ; ceux-ci visaient le rétablissement des populations de poissons lourdement touchées par une pêche excessive. L'évaluation scientifique de ces structures a débuté en 1930. En moins de deux ans, une équipe de recherche du Michigan a déclaré avoir obtenu un accroissement des populations de poissons. Dans les années 1930, une main-d'œuvre bon marché et des projets de conservation subventionnés par le gouvernement et supervisés par le Civilian Conservation Corps ont concouru à étendre à grande échelle l'emploi des techniques du Michigan et ce, avant même qu'une évaluation adéquate des effets à long terme de tels dispositifs ne soit complétée. Le début de la Seconde Guerre mondiale a temporairement interrompu les efforts de conservation gouvernementaux et a empêché l'évaluation suivie des structures en place. Durant les années 1940, 1950 et 1960, le design de ce type de structures est demeuré pratiquement inchangé et les quelques recherches réalisées pour évaluer leur impact se sont souvent révélées erronées. L'usage continu de ces dispositifs primitifs a contribué à corroborer la fausse croyance selon laquelle leur effet bénéfique sur les poissons était démontré. Même maintenant, l'utilisation de ces structures aménagées dans les cours d'eau continue à reposer sur les plans rudimentaires élaborés autrefois dans les Catskills, malgré les problèmes relatés dans la littérature quant à leur emploi.
ZUSAMMENFASSUNG Entwicklung der eingerichteten Wasserbiotop Verbesserungstrukturen in Stromrinnen der Vereinigten Staaten : das grosse Experiment in Fischerei Verwaltung. In den Vereinigten Staaten hat die Anwendung von instream Strukuturen zur Verbesserung des Wasserbiotops eine lange Geschichte. Die erste veröffentlichte Anwendung von solchen Konstruktionen in den Vereinigten Staaten fand in der Catskills Gegend von New York statt. In den Jahrzehnten vor der Großen Depression brachte die Pionierarbeit reicher Großgrundbesitzer eine Reihe von Entwürfen hervor. Die wissenschaftliche Auswertung dieser Strukturen begann jedoch erst in den dreißiger Jahren in Michigan. Innerhalb von zwei Jahren vermeldete das Michigan-Forschungsteam große Erfolge bei der Erhaltung der Fischbestände. Noch bevor die notwendige Überprüfung der langfristigen Wirkungsweise in Michigan abgeschlossen wurde, ermöglichten billige Arbeitskräfte sowie die durch die Regierung unterstützten Naturschutzprojekte unter der Leitung des "Bürgerlichen Naturschutzbunds" (Civilian Conservation Corps) die weitverbreitete Übernahme der Michiganer Methoden. Den Naturschutzbemühungen der Regierung setzte der Ausbruch des Zweiten Weltkrieges ein vorläufiges Ende und verhinderte die weiteren Auswertungen der schon installierten Strukturen. In den vierziger, fünfziger und sechzsiger Jahren blieb der Entwurf von instream Strukturen im Grunde unverändert. Unterdessen waren die wenigen Studien, die zur Auswertung der Wirkungsweise von instream Strukturen durchgeführt wurden, oft mangelhaft. Die fortgesetzte Anwendung von ähnlichen Struktur-Entwürfen aus den dreißiger bis sechzsiger Jahren trug dazu bei, daß sich die falsche Überzeugung etablierte, wonach instream Strukturen den Wasserbeständen von erwiesem Vorteil seien. Auch die moderne Anwendung von instream Sturkturen verläßt sich weiterhin auf die Grundentwürfe aus den Catskills, trotz der belegten Probleme mit der Anwendung solcher Pläne.

Manuscrit reçu le 19 juin 2002 ; manuscrit révisé accepté le 27 avril 2003

* E-mail address: dmtho@ conncoll.edu 


\section{INTRODUCTION}

Instream structures are used to create or improve habitat and have been utilized since at least the 1880s in the United States (U.S.) (Van Cleef, 1885) and even earlier in Europe (Hubbs et al., 1932; Hazzard, 1937). Throughout this history, habitat structures were prized for their ability to improve conditions for game fish (Hewitt, 1931; Hunter et al., 1941; Shetter et al., 1946; Saunders and Smith, 1962; Olson and West, 1989; Shields et al., 1995). However, the use of habitat structures also resulted in many failures that included the destruction of structures by floods (Hewitt, 1931; Aitken, 1935; Ehlers, 1956; Babcock, 1986; Hamilton, 1989; Frissell and Nawa, 1992; Thompson, 2002), a reduction in aquatic species diversity (Cooper and Knight, 1987) and disruption of invertebrate populations (Madsen, 1938). Habitat-structure use is discouraged by some researchers because of its unnatural appearance, the introduction of undesirable and nonbiodegradable materials, and the long-term negative impacts of the restoration projects themselves (National Research Council, 1992; Iversen et al., 1993; Thompson, 2002). Furthermore, many restoration projects are not adequately evaluated to determine their impact on aquatic species and channel morphology (Tarzwell, 1938; Olson and West, 1989; Frissell and Nawa, 1992; National Research Council, 1992; Kondolf, 1995; Muhar, 1996; Van Zyll De Jong et al., 1997). The majority of evaluations conducted also gauge the success of projects less than five years after completion (i.e. Hubbs et al., 1932; Madsen, 1938; Hunter et al., 1941; Shetter et al., 1946; Saunders and Smith, 1962; Hamilton, 1989; Olson and West, 1989; Shields et al., 1995). It is therefore difficult to determine if instream structures are effective in the long term to reverse habitat degradation that results from anthropogenic impacts. Despite these problems, the use of habitat enhancement structures continues to be a dominant practice in fisheries management in the U.S. (Hunter, 1991; Seehorn, 1992; Rosgen and Silvey, 1996; Riley, 1998). To understand how the practice of using instream structures became so widespread in the U.S., it is worth reviewing the historical development of these designs. This historical perspective shows that many of the problems with instream structures were reported more than 60 years ago when the designs were first being evaluated. Despite these problems, the design and use of habitat improvement structures in the U.S. changed very little during the 20th Century.

\section{COMMON INSTREAM STRUCTURES USED IN HABITAT RESTORATION}

Throughout this paper there are references to different types of stream-improvement structures. This warrants a general description of their appearance and functions to aid the reader in noting the similarities and changes that occurred historically. Although designs, materials, and construction techniques vary slightly through time, the general characteristics of each type of structure remain consistent. Over the last 70 years, three basic categories of structures persisted: dams, deflectors and cover structures or shelters. Each of the dams, deflectors and cover structures described are designed to improve habitat conditions for game fish by increasing water depth and providing hiding places for fish. Instream structures are usually employed to improve conditions for a single target species. In fact, most of the designs were developed exclusively to improve the size and number of salmonids.

\section{DAMS}

Much of the earliest design work focused on water impoundments created by small dams. Dams can be divided into three basic groups depending on the type of material used (Fig. 1). Loose rock or boulder dams are simple straight designs or arched rock dams now called vortex weirs (Hubbs et al., 1932; Rosgen and Silvey, 1996). Log dams take many forms including, log sills (Hubbs et al., 1932; Hunter, 1991), K-dams (Tarzwell, 1938), wedge dams (Tarzwell, 1938), timber-crib dams (Arthur, 1936) and cantilever, plank or board dams (Arthur, 1936). Dams in this last group also are called Hewitt dams (Hubbs et al., 1932). Finally, check dams are simple designs created from a number of man-made materials including gabions, concrete, masonry and sheet piling (Hubbs et al., 1932; Arthur, 1936; Gee, 1952). Although underpass logs or digger logs (Arthur, 1936; White and Brynildson, 1967) do not function as true dams and allow water to pass beneath the structure, they possess many of the same construction characteristics as dams and can be included in this general category.

\section{DEFLECTORS}

One of the most popular types of devices is used to deflect water and create scour. Deflectors come in a range of designs and construction materials, and often are named after the letter they most closely resemble (Fig. 2). Designs placed along the banks of a channel include peninsular-wing designs, peninsular-wing deflectors with chutes and triangular deflectors (Hubbs et al., 1932; Tarzwell, 1938). These types of deflectors are often paired on opposite banks creating V-deflectors for paired peninsular-wing designs and Ydeflectors for paired peninsular-wing deflectors with chutes (Hubbs et al., 1932). Spurs, spur dikes, jetties or groins are essentially the same design as peninsularwing deflectors and are used for both bank protection and habitat development (Richardson et al., 1990; Shields et al., 1995). Mid-channel designs include I-deflectors and A-deflectors (Hubbs et al., 1932). Unfortunately, A-deflectors also are called inverted V-deflectors (White and Brynildson, 1967) or simply V-deflectors (Arthur, 1936) creating some confusion with similarly named, paired-deflector designs.

\section{COVERS}

The last major category of designs includes structures called covers and shelters. Cover structures generally are not named as extensively as other types of structures. However, several general types of structures exist (Fig. 3). Designs for bank-cover structures include bank cribs (Seehorn, 1992), channel constrictors (Seehorn, 1992), raft and boom covers (Greeley and Tarzwell, 1932), and log and brush shelters (Hubbs et al., 1932). Mid-channel cover designs include half logs, tepee covers, stump covers and square covers (Hubbs et al., 1932; National Research Council, 1992). Logs and brush also are placed in mid-channel locations and simply called cover (Hubbs 


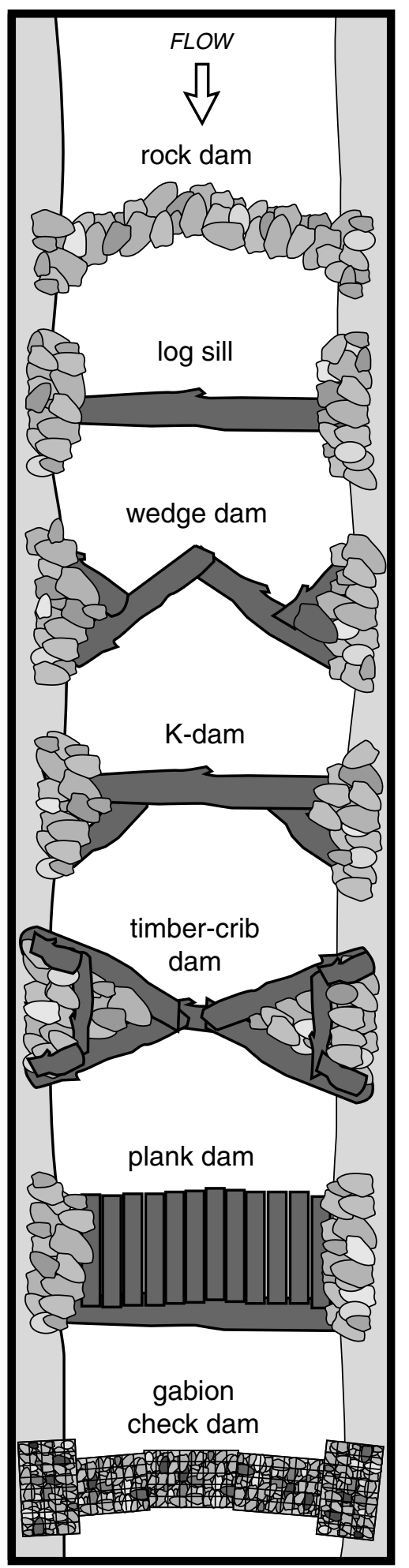

FIGURE 1. Common designs of rock and log dams used for habitat improvement.

Designs courants de digues de roches et de bois utilisées pour l'amélioration de l'habitat.



FIGURE 2. Various types of log and rock deflectors used to improve aquatic habitat. The triangular and peninsular deflectors can appear as single units or in paired designs.

Différents types de déflecteurs de bois et de roches utilisés pour améliorer l'habitat aquatique. Les déflecteurs triangulaires et en forme d'ailes sont composés d'un seul élément ou d'une paire d'éléments. 
et al., 1932), although the terms Wisconsin cover log and porcupine are used to describe these approaches (Hunter, 1991). Similarly, people create cover by simply attaching felled timber, also called large woody debris (LWD), to streamside trees with cables. Finally, randomly placed boulders are used to create additional cover along channels (Arthur, 1936).

\section{THE HISTORY OF INSTREAM STRUCTURES IN THE UNITED STATES}

It is easier to describe the various types of structures used in restoration than to determine when they were first introduced. Although humans historically lived near rivers, little is known about early attempts to modify rivers to alter habitat conditions. Undoubtedly, early anglers experimented with placing large rocks in streams to create better fishing. The first book in English to discuss fish culture and conservation was Leonard Mascall's, Booke of Fishing with Hooke and Line, written in 1590 (Parry, 1932). In contrast, pioneering efforts in fisheries management in the U.S. seem to originate in the Catskills region of New York almost 250 years later.

\section{THE PRIVATIZATION OF FISHING AREAS: PRE-1885}

On the Beaverkill River, one of the Catskill region's most famous trout streams, the first stocking of fish occurred in 1833 (Van Put, 1996). Eventually, fishing became more popular in the region and resort hotels were established in the 1840s and 1850s to support the sport (Van Put, 1996). The increase in fishing interest coincided with a decline in fish numbers (New York Times, 1887). In the Atlantic States, dams and obstructions to the river were viewed as a major cause of the degraded fisheries (MacDonald, 1884). To combat the problem of dwindling fish populations, one popular nationwide movement called for the installation of fishways on dams (Anonymous, 1876; Norton, 1880; Gilbert, 1881; MacDonald, 1883; Rogers, 1888; Wheeler, 1888). Fishing advocates also complained about declines in fish stock as a result of overfishing, asked for legal fishing limits to protect existing fish, and demanded artificial propagation to rebuild fish populations (MacDonald, 1884; New York Times, 1887). By 1874, the overfishing problem was so serious that legislation was introduced at the state level to place a two-year moratorium on trout fishing in two Catskills counties. The bill ultimately passed the New York Assembly but failed in the Senate (Van Put, 1996).

As fishing pressures increased and fish populations suffered, wealthy individuals sought ways to preserve their beloved hobby. In 1868, the Willowemoc Club was formed, which began a process of privatizing Catskills fishing areas for the exclusive use of club members (Van Put, 1996). James Spencer Van Cleef, the club founder and a resident of Poughkeepsie, New York, believed that privatization of trout waters by clubs was the only way to preserve trout waters. He and his fellow club members purchased thousands of acres of trout fishing waters in the region. In the 1870s, the club even constructed artificial spawning beds and cleaned streams of siltation, debris and barriers (Van Put, 1996). Van Cleef (1885) provided one of the first published references on the topic of channel restoration in the U.S. In this paper, he recommended the placement

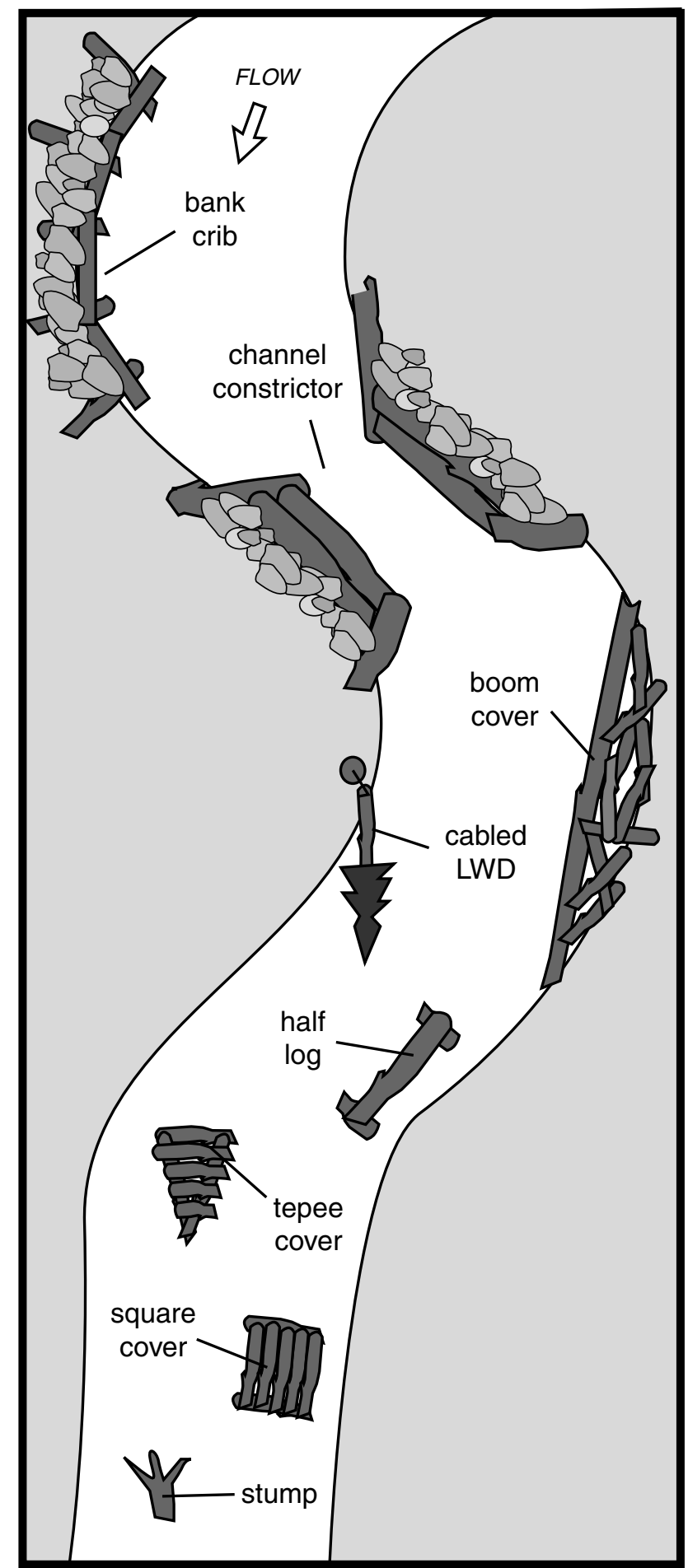

FIGURE 3. Common cover structures used to improve shelter in channels. Bank cribs and boom covers typically are used along the outside of bends. Cabled LWD and stumps can be used in a variety of locations. The remaining covers generally are placed in straighter reaches. Structures d'abri couramment utilisées pour améliorer les refuges dans les cours d'eau. Les abris en rive (bank cribs) et les abris en estacade (boom covers) sont habituellement installés le long de la rive externe des méandres. Des billots flottants maintenus à la rive et des souches peuvent être utilisés en différents endroits. Les autres types d'abris sont généralement placés le long de tronçons rectilignes. 
of LWD to replace habitat destroyed by anthropogenic influences (Van Cleef, 1885). Van Cleef eventually became more involved in public policy and wrote the general fish and game laws for New York State (Van Put, 1996).

The Willowemoc Club initiated a general trend of privatization with minor stream modification to improve fishing on club grounds. By the 1890s, almost all of the upper Beaverkill River was in private hands and posted for no fishing to the general public (Van Put, 1996). The importance of these private clubs and sportsmen's organizations continued to grow well into the next century (Osburn, 1923). By 1974, only a little over $1600 \mathrm{~km}$ of New York's $27000 \mathrm{~km}$ of trout streams were in public ownership (Otis, 1974). A survey of current conditions on the Beaverkill River, based on a site visit by the author, reveals that almost the entire upper $46 \mathrm{~km}$ of the river is posted to exclude public access. The loss of public fishing areas in the late 1800s placed even more pressure on the remaining aquatic resources to supply the region's growing population of fishermen and created a simultaneous demand for more private trout preserves in the region (Van Put, 1996). Streams and springs were dammed to create many of the desired fishing areas. Many of these artificial lakes and ponds had associated trout hatcheries run by clubs to support their own demands (Van Put, 1996). According to a report by Cheney (1900), the New York Commissioner of Fisheries, Game and Forest, private clubs were taking the leading role in developing new hatchery technologies. Eventually state and federal governments became more active participants in the production of trout (Trexler, 1897; Leach, 1919; Schley, 1971).

While the number of hatcheries increased, there was a simultaneous realization that stocking alone could not overcome the problems of poor fishing practices, especially the crisis of overfishing (Van Cleef, 1885; Armistead, 1920; Ingraham, 1926; Hewitt, 1934; Feast, 1938). Despite limited knowledge about the number of fish that could be supported by native waters, it became standard procedure to stock large numbers of fish during the late 1800 s and early 1900 s (Forbes, 1910). Scientists soon realized that overstocking was wasteful and should be halted (Forbes, 1910; Ingraham, 1926). As early as 1885 , fishermen also recognized that the reduction of trout populations in the Catskills was at least partially the result of the loss of physical habitat accompanying deforestation (Van Cleef, 1885). Similarly, individuals in the Midwest became concerned about the effects of erosion on natural habitat in small streams (X.Y., 1887). Van Cleef (1885) even suggested that trout restocking was pointless until the lost physical habitat was 'restored' by replanting streamside vegetation and replacing LWD in pools. Interestingly, the idea to add LWD to pools also was motivated by the desire to prevent the use of fishing nets and encourage sport fishing with fly rods (Van Cleef, 1885; Mottram, 1928). As the 1800s came to a close, fishermen continued to look for ways to combat the problem of overfishing and improve conditions for trout.

\section{STREAM IMPROVEMENT BECOMES A PASTIME FOR THE WEALTHY: 1892-1931}

During the end of the 19th century and the beginning of the 20th century, trout populations in the U.S. continued their decline. Overfishing became more of a problem due to increased demand, better equipment and the introduction of the automobile, which allowed for better access to remote locations (Surface, 1902; Osburn, 1923; Ingraham, 1926; Hewitt, 1931). Concerned fisherman reported great loss of fish life from a range of types of pollution that included sewage, ashes, sawdust, coal dust, oil and starch (Surface, 1902; Henshall, 1906; Osburn, 1923). Land-use impacts from deforestation, log drives, removal of LWD, swamp draining, river straightening, dam construction, and flow reduction from canals and irrigation also damaged fish stocks (Van Cleef, 1885; Surface, 1902; Osburn, 1923). As one concerned citizen reported, fish had supplied a common food element for the working class but now was exclusively a delicacy for the wealthy (Surface, 1902). In the U.S. in response to the failure of stocking to improve fish populations, wealthy landowners and clubs experimented with techniques to increase the number of fish, and pioneered efforts to use habitat-improvement structures (Hubbs et al., 1932).

On the Beaverkill River, milldams were common in the 1880s but largely gone 30 years later (Van Put, 1996). Although sawdust from the sawmills created problems for trout (Forbes, 1910), milldams reportedly provided some of the best trout habitat along this river (Van Put, 1996). It is entirely possible that the first habitat improvement structures in New York were created to replace fishing areas lost with the removal of milldams. Whatever the initial inspiration, Colonel O'Dell began a program of stream improvement with habitat structures in 1892 in the Catskills. He hired a local sawmill operator to install instream structures on the Beaverkill River using oxen. These structures were small dams (Van Put, 1996) that pounded water in a manner similar to milldams. The dam was a fairly simple design with a log positioned across the channel and large, flat boulders placed on the log, angled upstream to make a continuous dam (Fig. 4). Remarkably, many of the original structures still exist on the river today (Van Put, 1996). Using evidence collected during a site visit to the area, this design was popular in private trout waters along the upper Beaverkill River and many examples can be found near Turnwood, New York. At this location, the Beaverkill River has a cobble and bedrock substrate, a drainage area of $68 \mathrm{~km}^{2}$, a channel width of over $10 \mathrm{~m}$ and a channel-bed slope of 0.012 . This design of structure currently exists along a reach of river at least $3.2 \mathrm{~km}$ in length.

Although private individuals made modifications to improve their rivers in the 1910s (Tarzwell, 1935), state and federal agencies did little to study channel restoration or improvement techniques (Hubbs et al., 1932). For example, the Pennsylvania Fisheries Department constructed 16 fishways in 1904, but did not even mention stream-improvement work in the state's annual report (Meehan, 1905). Conversely, the structural approach to fisheries management spread in the private sector and most of the privately held water on the upper Beaverkill contained instream structures by 1930 (Van Put, 1996). It is safe to assume that most of this early enhancement work was conducted at the reach scale by individual property owners interested in improved fishing on their private stretch of river. Surviving structures on the Beaverkill, Willowemoc and 


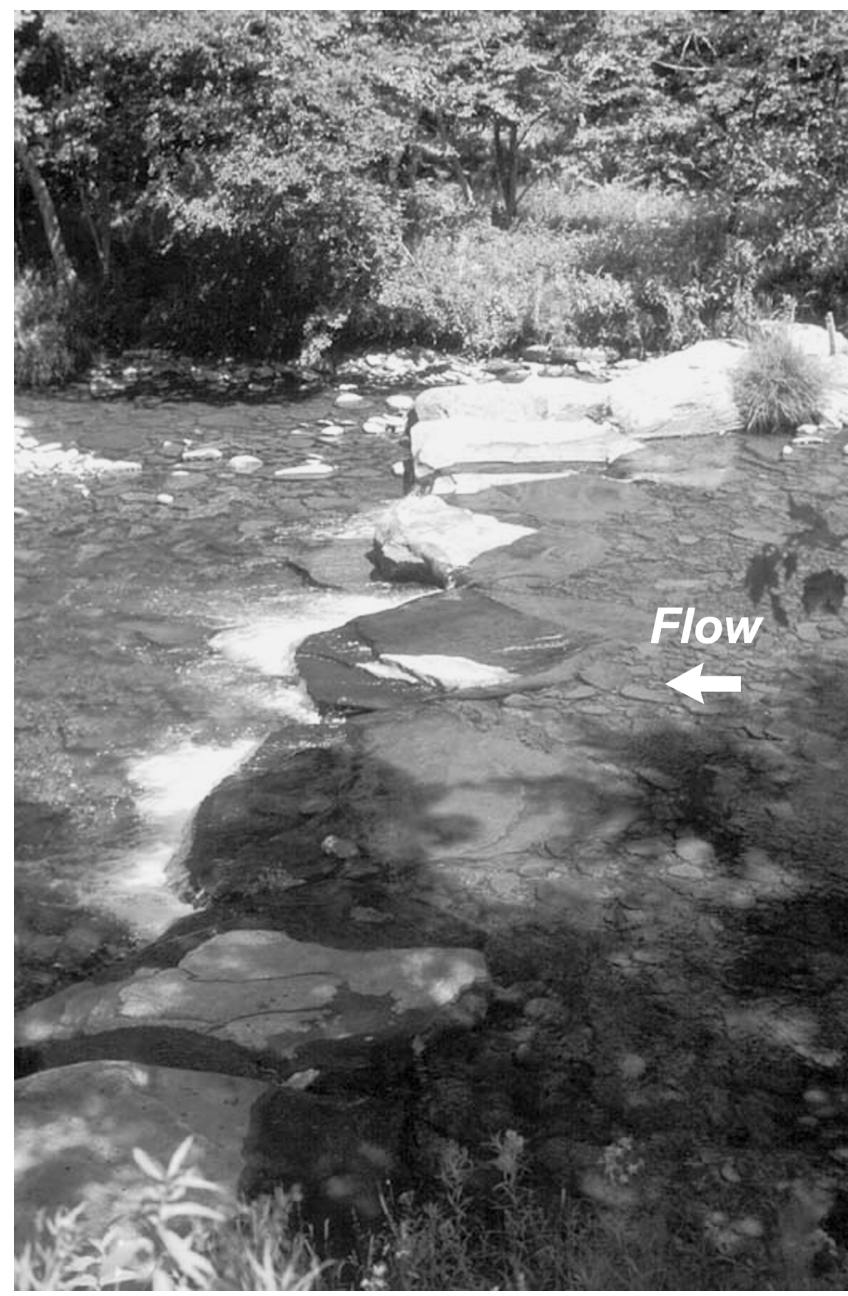

FIGURE 4. Log and rock dam along the Upper Beaverkill River. The support log is hidden under the downstream end of the rock-dam facing. Colonel O'Dell originally constructed this structure in the 1890s. Une digue de bois et de roches le long de l'Upper Beaverkill River. Le billot de support est caché sous la partie aval du revêtement en pierre. Cette structure a originellement été construite par le Colonel O'Dell dans les années 1890.

Neversink waterways show reach-scale variations from property to property consistent with this idea.

Although the Catskill Region of New York contains early examples of American restoration work (Van Cleef, 1885; Van Put, 1996), many of the stream-restoration practices used in the U.S. originated in Europe (Hazzard, 1937). In England, owners of a property hired keepers to conduct habitat work. The owners then leased the right to fish the property to wealthy individuals (Mottram, 1928). Although keepers practiced stream improvement for generations, professional jealousy reduced information exchange (Hubbs et al., 1932). Therefore, it is not clear if Americans were aware of specific designs from Europe. However, several European publications were produced by wealthy leaseholders that made an impression on early American anglers.

In one early British book on trout management, Armistead (1920) considered nature the primary factor in the health of streams but suggested that humans could improve upon natural conditions. He proposed the use of barriers in streams to increase water depth and recommended artificially widening rivers. Armistead (1920) discussed the problem of low baseflow conditions that resulted from a reduction in flood attenuation with the expansion of anthropogenic drainage system and the removal of debris. This early work drew a link between physical conditions in rivers and the health of game fish, and influenced American authors (Ingraham, 1926; Hubbs et al., 1932). However, there are few details provided on the design of structures.

In 1928, J.C. Mottram produced another British publication that influenced American management practices (Hubbs et al., 1932). According to the author, fisheries management was similar to farming; food supply was the key limitation and constant maintenance was required to maintain favorable conditions for trout (Mottram, 1928). He even stated, "a fishing [spot] is like a garden: never perfect, never finished". Many of the practices outlined by Mottram included yearly maintenance by full-time employees. Clearly, cost was not considered a hindrance in the effort to achieve better fishing. To overcome habitat and food limitations, physical modifications also were recommended. Practices included the placement of random boulders, the construction of log and wire dams to provide aeration and deep water, and riparian plantings to narrow channels, promote food growth and provide shade for the streams that have been artificially widened. Mottram also described deflectors in Norway that were 20 years old, constructed of large logs and gravel, and set at an angle of $45^{\circ}$ to the bank. He even suggested using stone or log deflectors on alternating sides of the channel to create a sinuous flow path. Mottram reported that these various modifications were applicable to all streams and easy to devise.

The ideas forwarded by both Armistead, (1920) and Mottram (1928) influenced fisheries management thinking in the U.S. (Hubbs et al., 1932). Furthermore, the publications coincided with a critical period of technological development. Before this time, little was know about the ideal habitat of river fish (Forbes, 1910). As early as 1910, people discussed the need to study natural rivers to determine how to improve conditions for fish (Forbes, 1910). However, neither the government nor academia began an organized effort to study stream improvement during the early 1920s (Hubbs et al., 1932). In contrast, individuals in the Catskills continued their localized improvement projects. This work eventually led to several New York-based trout management books that began to discuss the idea of stream improvement (Ingraham, 1926; Hewitt, 1931, 1934).

Henry A. Ingraham (1926) produced a book that was both revolutionary and remarkably revealing. In particular, the book highlights the role that elitism played in American fishing culture. Unlike other books of the time (Armistead, 1920; Mottram, 1928; Hewitt, 1931), Ingraham (1926) discussed the detailed scientific principles of geology, hydrology and ecology with specific reference to their importance for fish. At this time in history, Ingraham was unique in his discussion of the role that rivers play in transporting sediment through a watershed, and the tendency of rivers to migrate across a floodplain. He took 
considerable time to explain the role that forests play in infiltration and flood attenuation. He clearly discussed the importance of the food chain and the interdependence of species in an ecosystem. He also acknowledged the limitations in fisheries-management practices of the time with an over reliance on stocking, problems of introduced exotic species, possible adverse effects of the eradication of predatory species, and the failure of fishways to provide fish passage. Ingraham also was remarkably prophetic in his foretelling of the increased importance that hydropower would have on water resources. He recognized both the need for government pressure to force factories to recycle and find markets for waste products, and the role that fish licenses would play as a primary source of income for state fisheries departments. Ingraham was quick to point out the limitations of science and warned against making decisions that could not be easily reversed. Many of his ideas were remarkably advanced for the time and mesh easily with today's ideals.

Despite Ingraham's progressive thinking for the time, he defended a tradition of elitism for individuals wealthy enough to own trout preserves (Armistead, 1920; Mottram, 1928; Hewitt, 1931). Ingraham (1926) justified the privatization of fishing waters with the claim that wealthy landowners provided conservation of resources for the benefit of all. He suggested that public fishing of these same areas would lead to a depletion of populations. He even recommended that trout be regarded primarily as a sportsman's fish and no longer simply considered a food source. Furthermore, he wanted laws prohibiting the sale of trout, a step that was designed to close markets to poachers and reduce the theft of fish from clubs and estates. In fact, the problem of poaching on private waters was a common theme for authors of the time (Ingraham, 1926; Mottram, 1928; Hewitt, 1934). Ingraham (1926) reminded his readers that laws prohibiting poaching were in existence since the 16th century. He also advocated for 'severe' punishment of trespassers. Although he recognized the need for public fishing, Ingraham suggested that it was the role of the government to supply this demand. He believed the government should purchase large tracts of headwaters and prevent fishing on these small streams because of their importance as rearing areas for young trout. In contrast, he argued against similar fishing restrictions on private streams due to their anticipated unpopularity. Ingraham even proposed the establishment of an English approach to leased fishing rights, where farmers would maintain and sell admission to their rivers. This idea of leased rights would eventually develop into a licensing program employed by New York State to provide the public with fishing access for a fee.

One controversial Catskills property owner was particularly influential in the development of modern restoration techniques. In 1922, Edward R. Hewitt, an avid fly fisherman and wealthy New York City industrialist, purchased a large tract of land encompassing $7 \mathrm{~km}$ of the lower Neversink River (Hewitt, 1931; Van Put, 1996). Records from U.S. Geological Survey streamflow-gaging station (01435000), located just upstream of Hewitt's old property, indicate that the Neversink River has a drainage area of $172 \mathrm{~km}^{2}$ and an active width of over $35 \mathrm{~m}$. The channel is cobble-bedded, with local sedimentary outcrops and a channel-bed slope of 0.006 . After purchasing the land, Hewitt closed the area to public fishing. The public was furious, and this incident helped force the state to search for public fishing areas (Van Put, 1996). Ironically, the public-fishing areas acquired by the state would later be modified, using techniques advocated by Hewitt, to overcome overfishing on limited public acreage.

Hewitt (1934) introduced his first structures in New Jersey as a 'young man,' and supervised construction of structures on his Neversink property in the early 1920s. Hewitt (1931) claimed 50 years of interest in the subject and admitted to influences from Europe including England, Scotland, Germany and France. Nevertheless, he stated that most of his fishing experience originated in New York, New Jersey, Connecticut, Massachusetts and Pennsylvania (Hewitt, 1931). According to comments in Ingraham's (1926) book, both men were in communication and influenced each other's ideas. Hewitt (1934) also credited Arthur Marks, a property owner on the Beaverkill, with several unique and innovative designs. Despite these contacts, Hewitt (1934) complained about the lack of information on stream improvement, which he admitted led him to make many early mistakes. Eventually, Hewitt (1931, 1934) developed strong ideas about stream improvement and influenced channel-restoration ideas in the U.S. for decades (Hubbs et al., 1932; White and Brynildson, 1967).

Hewitt (1931) was particularly concerned with problems of overfishing and suggested the use of fees and restricted access to improve fishing (Hewitt, 1931). However, Hewitt's key contribution was the recommendation to spend money to improve waters, not artificial stocking. He claimed that state fish commission's efforts centered on raising and stocking trout for fee-paying sportsmen because the commission did not control enough land to manage the resources effectively. Hewitt argued that streams were overstocked and spawning grounds already were adequate for natural reproduction. Instead, he advocated for a system of instream structures to enhance physical habitat along rivers. He believed that with enough money and effort, good fishing was possible anywhere.

Hewitt's real legacy involved the design of a low-head dam that eventually bore his name (Cumings, 1932; Hubbs et al., 1932; White and Brynildson, 1967), and remains in use today (Hunter, 1991). Hewitt (1931) believed dams were cheap, permanent structures that provided cover, greater water depth and width, and slower velocities. Dams help stop bedload movement, which he felt was a very destructive force. His opinion was based on an incident were several trout were buried along his property during a flood. However, three years later Hewitt (1934) warned against the overuse of dams due to problems encountered with bedload transport and the warming of waters. He estimated the expense of these dams at $\$ 0.30$ per meter length (\$3.40 adjusted for inflation to 1999) for an overall cost of $\$ 70$ to $\$ 80$ ( $\$ 770$ to $\$ 880$ adjusted for inflation to 1999) per dam (Hewitt, 1931). The first two designs Hewitt (1931) tried were not successful due to undermining. The third design is the, now standard, plank design with several longitudinal support logs to limit undermining of crosslogs (Hewitt, 1931). Hewitt also used tarpaper to prevent undermining with some designs, but later recommended against this material (Hewitt, 1934). A good illustration of the 
reach-scale mentality adopted by Hewitt (1931) regards the suggested use of a dam and screening to allow trout to move downstream but not upstream. Later, he recommended another design that prevented trout from moving downstream. Clearly, the purpose of these devices was to trap trout in a particular stretch of river for the owner's exclusive benefit.

Although best known for dams, Hewitt (1934) promoted the use of other structural measures that included cabled LWD in pools. He mentioned the use of log deflector structures angled at $45^{\circ}$ to the bank and 5 to $6 \mathrm{~m}$ in length, which extended across less than half the channel (Hewitt, 1931). He used a series of these deflectors along the outside of banks to prevent channel migration and cutoffs, and credited the Scottish with these designs that they called 'croys'. He even suggested making sinuous courses with alternating deflectors (Hewitt, 1934), an idea he may have adopted from Mottram (1928). Mid-channel deflectors were also presented in his later book, but little detail is provided on their use (Hewitt, 1934). In one of his most important observations, he warned that one or two seasons was not enough to properly evaluate the success of habitat structures. These comments were based on failures in his designs after what appeared to be promising short-term results.

By the early 1930s, Hewitt's work was widely known (Cumings, 1932; Hubbs et al., 1932) and specific reference to his designs occurred as late as the 1960s (White and Brynildson, 1967). Although limited stream-improvement work began in Michigan as early as the mid-1920s, Hewitt even influenced this early work (Cumings, 1932). Despite Hewitt's lasting influence, it is clear that he was a bit of an eccentric and an extremist when it came to trout fishing. He introduced exotic species that included the African paper-snail, to improve food availability on the Neversink River (Hewitt, 1931). In one instance, using knowledge gained in England, he experimented with the best food to supply his hatchery fish. Hewitt paid Long Island fisherman to collect mussels, boil the shellfish for five minutes to remove the shells, pickle the meat in salt, transport the food over $64 \mathrm{~km}$ to the Neversink River and wash it in the river for five hours in a special perforated drum. The mussels were then fed to trout to improve their growth rate. He later admitted that these trout were not hardy enough to survive the winter and needed to be caught immediately. Hewitt (1931) also proposed that money spent on hatcheries could be better spent on eradicating species that predicate on trout. The eradication of predatory species was a fairly widespread practice in early fisheries management (Armistead, 1920; Osburn, 1923; Ingraham, 1926; Mottram, 1928). According to leading trout-management books in the U.S. and Great Britain, ducks, herons, cormorants, kingfishers, owls, river otters, mink, muskrats, Norway rats, pike, eels, chub, suckers, frogs, water snakes and turtles near trout waters should all be shot or trapped (Armistead, 1920; Ingraham, 1926; Mottram, 1928; Hewitt, 1931). One Forest and Stream reader from New York even bragged about killing 189 kingfishers and using the feathers to make a pillow for his fishing camp (Anonymous, 1906). Hewitt (1931) listed additional trout enemies that included dragonfly larvae, crayfish, crows, osprey, raccoons and house-cats but provided no recommendation on what should be done with these species. He even recommended the removal of trout over three pounds in size because of their predatory instincts, a sentiment echoed by both Armistead (1920) and Ingraham (1926). It appears that Hewitt and his contemporaries (Armistead, 1920; Ingraham, 1926; Mottram, 1928) believed that any form of artificial manipulation of rivers and their biota was justified if it increased trout populations and improved fishing.

\section{CHEAP LABOR PROMOTES AN EXPANSION OF STREAM IMPROVEMENT: 1932-1941}

As described above, stream improvement in the U.S. was largely done on private estates and clubs before the 1930s (Hubbs et al., 1932; Tarzwell, 1935). Wealthy individuals dominated the early use of instream structures because they possessed the means to purchase large tracts of land and hire laborers to install and maintain the devices (Otis, 1974). Yearly maintenance costs were expected (Hewitt, 1931), but the cost was inconsequential compared to the huge investments made in acquiring and modifying large segments of river. There also was little concern or incentive to look beyond the confines of an individual property to determine possible effects of instream structures on the watershed as a whole. Despite these limitations, stream-improvement work would expand in less than five years from a small region in New York to a massive nationwide effort.

Although many techniques for modifying habitat in channels predate the 1930s, stream improvement was clearly a product of the depression (Hazzard, 1937). The first government and academic research began on the use of instream structures in the 1930s in North America (Swales and O'Hara, 1980). At this time, other scientific advances furthered understanding of the link between hydrology and aquatic habitat. As early as 1910, scientists recognized that floods provide an important function for the delivery of food from floodplains to rivers (Forbes, 1910). As explained by Burger (1932), foresters in Switzerland also fully understood how deforestation in mountain basins creates more surface runoff, higher peak flows and can lower baseflow conditions in many cases. Meanwhile, the 'Michigan School' of ichthyology arose under the influence of Carl L. Hubbs (Heins and Matthews, 1987). The name Hubbs would eventually become synonymous with stream improvement because of his research at the Institute for Fisheries Research at the University of Michigan.

Prior to Hubbs involvement with the Institute for Fisheries Research, Dr. Jan Metzelaar carried out experiments for the Michigan Department of Conservation with the reintroduction of LWD, a processes he called 'resnagging' (Hubbs, 1931). This work began in 1927, and involved cutting down trees and creating log jams with the downed timber (Tarzwell, 1935). Although Metzelaar became a U.S. citizen in 1929, two days before he died while conducting lake research for the Department of Conservation, he was born in the Netherlands and moved to the U.S. in 1922 (Hubbs, 1931). Therefore, he may have been more influenced by European practices than American management traditions. The Institute for Fisheries Research at the University of Michigan was formed in response to his death and the complete loss of key staff 
members in the Department of Conservation (Hubbs, 1931). This group represented the first professional organization focused on research in stream improvement (Hubbs et al., 1932). Funding was supplied by the Michigan Department of Conservation and the Izaak Walton League of America, a conservation group formed in 1922 in response to deteriorating conditions in top U.S. fishing streams (Hubbs, 1931). A key member of the staff was John S. Greeley, who was assigned the position of assistant to the director. Greeley came from the New York Biological Survey (Hubbs, 1931), and probably was familiar with the early stream-improvement work carried out in the Catskills. Hubbs et al. (1932) provided an annotated bibliography with several influential publications in one manuscript that included Armistead (1920), Ingraham (1926), Mottram (1928) and Hewitt (1931). They indicated that the book by Hewitt (1931) was the best American work on trout stream management methods at the time. Greeley and Tarzwell (1932) also claimed that the Hewitt dam had become well known by 1932 . Therefore, it is likely that many of the ideas practiced in the Catskills were directly adopted in Michigan.

Hubbs (1932) provided several key motivations for stream improvement that included the desire to shorten the time between bites and reduce the long walks between successive pools so "fishing would bear less resemblance to golf." Stream improvement was based on the theory that mere protection cannot grow fish and stocking was prohibitively expensive (Hubbs et al., 1932). Hubbs (1932) suggested that stream improvement provided the only means to meet the demands from very heavy fishing pressures. Pollution and siltation also were listed as two causes of degraded habitat (Hubbs et al., 1932). The Michigan group believed that "the stream can be modified almost to any degree desired," but noted an unknown point of diminishing returns (Hubbs et al., 1932). They suggested that long stretches of troutless water could be modified to yield a good catch in a few months; a process that must have relied on relocation of fish not improvements in fish survivability or growth. Hubbs (1937) later stated that: "The ultrapreservationists, as I call them, wish to prevent the sordid hand of man from further despoiling natural conditions; their interest in the natural relations between all forms of life is incompatible with fish management, which strives to modify the natural populations and the environmental conditions so that a few species desired by the sportsman will dominate the waters." Clearly, the Michigan group were not conservationists. Their focus was to use the methods of scientific management to maximize production in a manner similar to agriculture; a practice they called aquatic farming (Hubbs, 1937). In fact, the practice of stream improvement also was called 'stream farming' in Pennsylvania (Tarzwell, 1935).

The methods employed by the Michigan group included the use of dams, deflectors, and cover structures with additional streamside plantings to shade the water (Hubbs et al., 1932). Specific designs included dams, various wing deflectors, I- and A-deflectors, and fixed and floating cover structures. All structures utilized a low profile to avoid damage by floods, ice and rotting. Cover structures and deflectors often were combined to direct flow under the cover to keep these areas free from gravel. Deflectors also were used in pairs to improve their effectiveness (Greeley and Tarzwell, 1932; Hubbs et al., 1932). The authors even recommended the installation of structures in summer or early fall to take advantage of low water (Hubbs et al., 1932). They recommend the placement of 30 structures per $\mathrm{km}$ at a cost of $\$ 80$ per $\mathrm{km}$ (\$960 adjusted for inflation to 1999) for a typical 6- to 12-m wide channel. The structures used in Michigan from 1930 to 1932 cost from $\$ 1$ to $\$ 4$ each ( $\$ 12$ to $\$ 48$ adjusted for inflation to 1999) and labor constituted the major expense (Greeley and Tarzwell, 1932).

In developing stream-improvement techniques, Hubbs (1932) stated that methods must be adopted from other locales, but only after the methods were tested in the new area. Hubbs et al. (1932) declared that most people familiar with fishing and rivers could determine which improvements were desirable, and they believed that any installation was worthwhile. Work began on the Little Manistee River in 1930 (Hubbs et al., 1932) but within five years, $30 \%$ of the structures were destroyed (Tarzwell, 1936). Undaunted, Hubbs and his comrades installed approximately 1000 structures and monitored 900 of these devices in Michigan by 1932. Although Hubbs et al. (1932) expected that future improvements in stream management practices would make their techniques obsolete in a few years, modern publications continue to recommend carbon copies of devices used in Michigan in the 1930s (i.e. Hunter, 1991; Seehorn, 1992; Rosgen and Silvey, 1996). Hubbs et al.'s (1932) work also was referenced for decades (i.e. Gee, 1952; Saunders and Smith, 1962; White and Brynildson, 1967; Otis, 1974; Swales and O'Hara, 1980; Riley, 1998).

During the early 1930s, Franklin D. Roosevelt was elected president and introduced the New Deal that included Emergency Conservation Work, commonly called the Civilian Conservation Corps (CCC) (Hubbs et al., 1933). Although the CCC mandate initially did not include stream improvement, it officially adopted this function by 1933 (Hubbs et al., 1933). The availability of CCC labor created a substantial impetus for conservation work (Greeley, 1935; Fechner, 1936). The dramatic increase in 1930s stream improvement also resulted from an increased demand for better fishing and the recognition that habitat conditions were essential to fish survival (Greeley, 1935). Finally, people recognized that under the increased fishing demands of the time period, stocking alone could not improve fishing (Lord, 1935; Feast, 1938).

Although the structures in Michigan were introduced and tested for only a period of four years (Hubbs et al., 1932), the methods used by the Institute for Fisheries Research were adopted for use nationwide (Hubbs et al., 1933; Aitken, 1935; Tarzwell, 1936; Feast, 1938; Madsen, 1938). The Michigan work was expanded to lowa and Wisconsin in 1932 (Tarzwell, 1935). In 1933, in response to Hubbs et al.'s 1932 publication, work spread to other regions of the country. By 1934, CCC streamimprovement projects were initiated on public land all over the country in places that included Arizona, California, Connecticut, Colorado, Idaho, Nevada, New Jersey, New Mexico, New York, North Carolina, lowa, Michigan, Minnesota, Montana, Nevada, North Dakota, Pennsylvania, Utah, Virginia, West Virginia, Wisconsin and Wyoming (Hubbs et al., 1933; Greeley, 1935; 
Tarzwell, 1935; Madsen, 1938; Tarzwell, 1938). CCC camps eventually were established in every state with more than 1500 camps of 200 men each (Riley, 1998). U.S. Forest Service (USFS) and U.S. Soil Conservation Service personnel oversaw technical aspects of these projects (Hubbs et al., 1933). This expansion occurred despite the fact that the Michigan group realized an early problem with stream improvement was the introduction of techniques from one region to other areas where the techniques were unsuitable (Tarzwell, 1935).

The projects were considered experimental and a trial-anderror approach was adopted (Feast, 1938; Madsen, 1938). In at least some regions, instream structures were placed without a preliminary survey of the channel (Tarzwell, 1938). Many of the early installations were lost, but fewer losses occurred in subsequent years (Hubbs et al., 1933). One reason given for early problems originated from the fact that many of the workers in the CCC came from urban areas and had never seen a trout stream before the CCC projects were initiated (Hubbs et al., 1933). Between 1933 and 1935, a total of 31084 structures were constructed on 406 mountain streams (Hunter, 1991). By 1936, the CCC had 'improved' $7950 \mathrm{~km}$ of stream, built more than 3800 rearing ponds and introduced nearly 200000000 fish in forest streams and lakes (Fechner, 1936). Clearly, work initiated by Hubbs et al. (1932) in 1930 created a dramatic national shift in fisheries-management practices that completely engulfed the field by the late 1930s. The rivers and streams experienced an entirely new type of anthropogenic influence on a scale that approached some of the more damaging human impacts of the past.

Eventually in 1936, the USFS produced its first handbook on the use of habitat structures (Arthur, 1936). According to the author, the designs in the manual drew heavily from works by the Conservation Department of the State of Michigan, the U.S. Bureau of Fisheries, and the Board of Fish Commissioners of Pennsylvania. Specific designs included masonry dams, plank dams, timber-crib dams, rock dams, individual log dams, triangular deflectors, peninsular-wing deflectors, V-deflectors, A-deflectors, cabled LWD, and random boulder placement. Contemporary CCC publications also mentioned designs for deflectors, rock dams, K-dams, wedge dams and single-boulder placement (Kylie et al., 1937). The USFS constructed these designs to handle the 10-year flood (Arthur, 1936). Overall, the design criteria are very detailed (Arthur, 1936) and were even more technical than those contained in some modern USFS publications (i.e. Seehorn, 1992).

Although stream improvement was conducted on a huge scale nationwide, few evaluations of the impacts of instream structures were completed. Despite a pool of CCC labor that reached 300000 men (Riley, 1998), Greeley (1935) complained that detailed studies were not possible because of the time and labor required to complete the evaluations. According to Tarzwell $(1936,1938)$, one of the original authors of the influential Hubbs et al. (1932) bulletin, assessment of improvements largely was neglected and almost no results were published. He stated that over a million dollars were spent on installation improvements, but only a few thousand on investigations (Tarzwell, 1935). Several other professionals indicated that more study was needed to demonstrate the value of stream improvement (Greeley, 1935; Arthur, 1936; Hazzard, 1937; Madsen, 1938; Hunter et al. 1941). Davis (1935), the chief of the Bureau of Fisheries, thought there was an over reliance on stream-improvement techniques and made an appeal for a more natural appearance to structures. Furthermore, he stated that the perceived benefit of stream improvement grew beyond its use as a management tool, especially in the mind of the average angler who saw stream improvement as a means to insure larger catches (Davis, 1935). Eventually, evaluations were completed to determine the impact of instream structures on rivers and aquatic habitat.

In most of the early evaluations completed, there was a heavy reliance on general observation and opinion (i.e. Aitken, 1935; Greeley, 1935; Feast, 1938). The ability of a structure to remain stable in the channel was one of the primary bases for success (i.e. Aitken, 1935; Greeley, 1935; Tarzwell, 1936; Feast, 1938; Madsen, 1938). Unfortunately, durability is not the best measure of success (Hunter, 1991). Finally beginning in 1936, more comprehensive evaluations were published. The first of these studies included a survey of 2235 structures on 18 different channels in Michigan (Tarzwell, 1936). The structures were evaluated for permanence, effectiveness and the physical and biological changes produced. Tarzwell (1936) concluded that the improvements were relatively stable, and increased the production of fish food. Later, he completed a more scientific evaluation of structures installed in Arizona. He used a paired-watershed, creel census to determine the change in the number and size of trout caught along an improved channel versus an adjacent stream. Along the modified channel, the size of trout deceased during construction but increased slightly for two years after completion of the project. At the time, the most statistically sound evaluation of stream-improvement techniques was conducted on the Blackledge River in Connecticut (Hunter et al., 1941). Hunter et al. (1941) conducted a two and one-half year study of wedge dams and concluded that the dams did improve temperature, dissolved oxygen, food availability and cover conditions for trout relative to riffle areas. However, more recent studies of structures installed in the 1930s on the Blackledge River raised concerns about the long-term impact of these devices that include increased bank erosion, decreased total bank cover and reduced growth of riparian trees (Thompson, 2002).

Even though stream improvement showed promise in some regions, many early evaluations contained disturbing trends. At the end of a two year survey in lowa, serious faults in Hubbs et al.'s (1932) methods were revealed, which emphasized the need for a combined engineering and biological approach to stream improvement (Aitken, 1935). Cover structures failed at a rate of almost $100 \%$ due to siltation problems. However, more success was found with the use of deflectors. Based on these results, a recommendation was made by Aitken that work needed to first center on reforestation and erosion control in the watershed before efforts were expended on instream structures. In 1938, Madsen reported disturbing findings on streamimprovement work conducted in Idaho, Nevada, Utah and Wyoming. Engineering defects were found in a large percentage of the structures with failure from undermining and outflanking most common. Enhanced erosion created by the structures also 
proved destructive to the stream's food organisms. Based on invertebrate sampling, evidence revealed that areas impacted by the structures contained $20 \%$ less food organisms than unaffected areas in June and $54 \%$ less food by August. There was no evidence of fish spawning in gravels created by structures for three seasons after installation. In addition, $95 \%$ of the floating shelters and cabled LWD were destroyed, while fish avoided the remaining structures because movement of the devices in the current scared the fish. Madsen concluded that stream improvement was not practical or economically sound in high-mountain streams. Despite these mixed results, structural approaches to fisheries management became well entrenched by the early 1940s, and heavily influenced restoration design in the modern era. Hubbs (1937) predicted that scientific fish management would 'develop enormously in the coming decade', but changes due to World War II soon put an end to most of these efforts.

\section{WORLD WAR II ENCOURAGES A PERIOD OF STAGNATION: 1942-1967}

It is fair to say that before World War II, modern designs of habitat structures were in widespread use in the U.S. even though evaluations of these structures were limited (Shetter et al., 1946) and contained many mixed results. It is also very important to note a general trend in the tone of scientific publications. Most of the earlier positive conclusions are produced by many of the researchers who were directly connected to the pioneering work in Michigan (i.e. Hubbs, 1931, 1932; Hubbs et al., 1932, 1933; Greeley, 1935; Tarzwell, 1936, 1938; Hazzard, 1937), while more critical findings tended to be developed by more distant researchers (i.e. Aitken, 1935; Davis, 1935; Madsen, 1938). Because the Michigan researchers were directly involved in development and promotion of many of the stream-improvement techniques tested, it is possible to question the objectivity of many of the early studies. In some cases, newly completed projects were heavily stocked to attract fishermen and promote the benefits of stream improvement (i.e. Tarzwell, 1935). All of the evaluations also focused on short time frames and probably documented relocation of fish towards structures, not basic changes in stream productivity. Leonard (1940) suggested that several years would be required before the channel bottom would harbor the full capacity of food organisms because many aquatic organisms require at least a year to complete their life cycle. Therefore, it is difficult to understand how a new structure could immediately change the overall productivity of a stream. Unfortunately, before long-term studies could be completed, World War II produced a lull in research activity.

By the 1950s, the stream-improvement work conducted in the 1930s by the CCC largely was forgotten (Ehlers, 1956). However, demand for installed devices continued, even though little was known about their value (Ehlers, 1956). Therefore, many of the lessons that could have been learned from the massive stream-improvement efforts of the 1930s were lost to designers. Meanwhile, the use of habitat structures became well established and drawings in modern design manuals show these same designs in continued use (i.e. Hunter, 1991; Seehorn, 1992; Rosgen and Silvey, 1996).
The only well-known study conducted between 1942 and 1955 in the U.S. was completed by Shetter et al. (1946) from the Michigan Department of Conservation. This investigation represented the first comprehensive before and after evaluation of stream improvement to be published (Swales and O'Hara, 1980), although some earlier CCC structures did exist at the site prior to the study, albeit in a damaged state (Shetter et al., 1946). In this investigation, twenty-three deflectors were installed in 1941, one deflector was installed in 1943, and five deflectors were installed in 1944 to replace earlier damaged structures. The study revealed a decrease in trout populations from 1941 to 1942, and an increase from 1942 to 1944. Although the authors attributed the increase in fish population to the existence of structures, there is little discussion of the effect that World War II had on the number of people fishing these streams. Nationwide, the number of people fishing should have dramatically dropped from the period of the Great Depression when many people were out of work and fished for food, to the World War II era when many people had enlisted in the military or were fully employed in war-related industries and had little time to fish. Shetter et al.'s (1946) data showed this trend. Total angling hours along the study reach before the war averaged 657 hours and dropped almost $19 \%$ to 538 hours during the war (Shetter et al., 1946). Despite this fact, they claimed that the increase in trout populations was due to placement of the deflector structures. However, the number of fish caught per hour increased more in one of the two untreated sections of the river than in the 'improved' section (Shetter et al., 1946), which again showed that changes in fishing pressure dominated results. It is also noteworthy that the researchers were working for the government agency that initially funded Hubbs. Regardless of the limitations of the investigation, this publication was viewed as evidence that stream improvement effectively increased trout populations (Swales and O'Hara, 1980).

In the mid-1950s, Robert Ehlers (1956) published one of the few long-term investigations of stream-improvement techniques. According to this study, an 18-year old USFS and CCC restoration project in California had $76 \%$ of the original 41 structures washed out or rendered ineffective. All rock deflectors, earth dams, arched dams, straight dams and plank dams washed out by 1953. However, many of the destroyed structures still persisted in the channel to create an aesthetic detriment. Early survey work by the CCC revealed that some of the structures did more harm than good. The structures required maintenance work in both 1936 and 1937, but no repairs were made from 1938 to 1953 . Ehlers concluded that even when structures were well built, constant maintenance was required if the structures were to perform their intended duty.

The next widely-known evaluation of habitat structures was not completed until 1962 (Saunders and Smith, 1962). In 1959, 25 dams and deflectors, and several cover structures were placed in a $411-\mathrm{m}$ reach with minimum spacing of $15 \mathrm{~m}$ (Saunders and Smith, 1962). The designs were based on those originally proposed by Hubbs et al. (1932). Thirteen of the dams were damaged by erosion around the sides of the dam and one was destroyed after one year. Conversely, fish populations nearly doubled during this period. However, the 
study was flawed because it made no attempt to compare results to control channels or to account for fish migration from other brooks. Saunders and Smith (1962) reported data that indicated up to one-third of the brook trout in the study reach migrated to other brooks in previous years, but the authors made no attempt to determine the effect of migration in their study. Regardless of these oversights, the study was believed to provide evidence that instream structures increased fish populations (Swales and O'Hara, 1980).

During the 1940s, 1950s and 1960s few innovations in the design or use of instream structures developed. In 1952, a new USFS stream-improvement handbook (Gee, 1952) was produced to replace the 1936 publication, but many of the designs were heavily influenced by the work conducted by the Michigan Department of Conservation. One of the few innovations appearing in this publication involved the use of gabion structures and sheet piling for habitat use. In characterizing the 1930s work, Gee stated that the earlier work focused on the use of a large variety of structures with the hope that this would solve many management problems. Reportedly, many mistakes were made in the 1930s work and the results of the work fell far short of making desirable stream habitat if problems existed in the watershed. Despite these warnings, Gee (1952) provided no counsel on the types of structures that failed and he even suggested that experienced streamimprovement foremen could devise their own types of instream structures. He also provided a recommended ratio of pool versus riffle areas, but later admitted that there was no scientific basis for these values. Finally, the handbook suggested blasting out pools and fishways in natural bedrock channels, although the author reported that the success of these attempts was not established at the time of the publication. It appears that the experimental approach to stream improvement adopted in the 1930s, survived into the 1950s.

\section{THE ENVIRONMENTAL MOVEMENT SPURS NEW INTEREST IN CHANNEL RESTORATION: 1967-PRESENT}

It is fair to say that the modern era in channel restoration began in the late 1960s as the environmental movement gained momentum. The number of publications on channel restoration increased dramatically versus previous time periods, and only a few key publications will be discussed in this paper. Although new scientific principles were employed to design restoration projects, the traditional use of instream structures persisted and strengthened. During this period, the first references to the use of geomorphic principles in designing restoration projects developed (i.e. White and Brynildson, 1967). Eventually, more sophisticated geomorphic principles were applied to the design of channel-restoration projects (Brookes and Shields, 1996a). Beginning in this period, geomorphologists began to document the physical changes that occurred in response to channelization, dams and the loss of LWD (Emerson, 1971; Keller, 1975; Nunnally, 1978; Keller and Swanson, 1979; Williams and Wolman, 1985). Still, many restoration manuals continued to rely on structures designed decades earlier (i.e. Cliff, 1969; Hunter, 1991; Seehorn, 1992; Rosgen and Silvey, 1996; Van Zyll De Jong et al., 1997). On a national scale, a prestigious federal task force recommended that nonstructural measures be given equal consideration when planning for flood control (National Research Council, 1992). These nonstructural measures included flood-warning systems and zoning to prevent occupation of the floodplain. The recommendations directly led to the establishment of the National Flood Insurance Program and the floodplain-mapping program (National Research Council, 1992).

In 1967, a new publication developed by the Wisconsin Department of Natural Resources (White and Brynildson, 1967) began to move away from some of the trends common in the 1930s. The book focused more on restoring channels impacted by human activities than improving natural systems. White and Brynildson suggested damage from cattle, dams, floods and dredging was the biggest problem in the 1960s. Pollution also was mentioned as a concern. The authors suggested expending more effort on preserving streams than altering them, and they argued against a cookbook style of stream improvement. They also recommended a holistic view of the watershed and warned novices not to undertake stream improvement. They suggested that trout fishermen were the most appropriate group to undertake the projects stating that "habitat management is primarily a problem of biology not engineering".

Christopher Hunter (1991) described the publication of White and Brynildson (1967) as a quantum leap that contained radical ideas on fisheries management, and stressed aesthetic values and an overall watershed focus. As an example, he suggested that the focus on bank vegetation versus structural approaches was novel. He also emphasized the importance of the new focus on pre-project planning in the book. Although White and Brynildson's (1967) publication contained new ideas, there were many references to the origins of stream improvement. They commented that in Europe, rivers were privately rented for hundreds of dollars per kilometer, which led to erosion control for centuries. They also included a detailed reference list that specifically mentioned the influence of Hewitt (1934) and they suggested that his methods were still valuable. The influence of Hubbs et al. (1932) also is clear in the document. However, many of the early designs used by Hubbs et al. (1932) fell out of favor, including V-deflectors, Y-deflectors, I-deflectors, A-deflectors and digger logs (White and Brynildson, 1967). Furthermore, sheet piling and concrete were discouraged as construction material because of their artificial nature. Although some progress is evident in the thinking of the time, beaver and LWD still were regarded as problems in fisheries management because they created migration barriers. White and Brynildson (1967) may have ushered in a new era of holistic management, but they also helped resurrect flawed designs of the 1920s and 1930s.

While advances in the science of channel restoration were made, attitudes towards instream structures largely remained unchanged in the 1960s. In 1969, the USFS produced a new stream-improvement handbook (Cliff, 1969) to replace older publications. Large sections of the text and design drawings related to instream structures were identical to the 1952 publication by Gee. However, the author admitted that many streamimprovement projects were unsuccessful in the past. The USFS handbook still suggested the use of instream structures to 
correct natural deficiencies of streams. Concern over bank erosion was so great that the USFS recommended placement of riprap or gabion revetments, and gabion mats with a trapezoidal shaped channel to prevent scour. The USFS even mechanically cleaned gravel with expensive gasoline-powered amphibious tractors, and ignored the important role that floods play to naturally maintain spawning gravels. The USFS handbook referred to floods as 'damaging' despite the earlier realization by geomorphologists that floods helped create the pool and riffle sequence needed by fish (Leopold et al., 1964). In fact, the 1969 handbook contained phrases about biological training and knowledge of stream ecology, but no mention of geomorphology or engineering (Cliff, 1969). In addition, a sixpoint project plan outlined in the document provided no mention of evaluation of projects to determine if restoration goals were met.

A range of publications in the 1970s and 1980s were produced that included a mixture of a new appreciation for the importance of a multidisciplinary approach to channel restoration and a continued reliance on the structural techniques of the past (Otis, 1974; Barton and Cron, 1979; Babcock, 1986). For example, Otis (1974) recommended restoration planning that included both fisheries biologists and engineers, but he later added that "a couple of fishing buddies" should spend time randomly rolling boulders into the middle of channels to form shelter even if it is only effective for one year. Barton and Cron (1979) believed the ideal habitat improvement involved the establishment of a stable pool and riffle sequence. However, they also recommended the use of peninsular-wing deflectors and dams similar to designs introduced by Hubbs et al. (1932) and Tarzwell (1938). Following a 25-year recurrence interval flood, an evaluation of the stream-improvement project completed by Barton and Cron (1979) revealed serious deficiencies in the performance of these structures (Babcock, 1986). One of the most influential papers in the 1970's was a product of the Wisconsin Department of Natural Resources (Hunt, 1976). The study described a ten-year study of deflectors and bank covers with designs derived from White and Brynildson (1967). The article concluded that the structures improved fish numbers and biomass. However, fish populations actually declined immediately following the enhancement work, a result that contradicts some earlier claims (i.e. Tarzwell, 1938; Shetter et al., 1946; Smith and Saunders, 1962). This study also represents another example of an evaluation conducted by the individuals responsible for the ultimate success of the project.

During the 1990s, increasingly more complex geomorphic guidelines were introduced (Brookes and Shields, 1996a; Thorne et al., 1997), but the traditional use of instream structures also continued unabated (Hunter, 1991; Seehorn, 1992; Rosgen and Silvey, 1996; Van Zyll De Jong et al., 1997). Some projects utilized structural measures to improve habitat and followed a trial-and-error mentality (National Research Council, 1992; Brookes and Shields, 1996b), a tradition passed down from the work in the 1920s and 1930s. The National Research Council (1992) also noted that published recommendations often follow a rule-of-thumb nature where 'experience' is substituted for a true scientific understanding. They warned that this intuitive approach to channel restoration could cause more unexpected harm than good. Furthermore, projects still focused on a single species and lacked consideration for the essential dynamic processes that shape river morphology (National Research Council, 1992; Muhar, 1996).

Modern books continue to echo the hopes and concerns common to fishermen in the early 1900s. For example, Hunter (1991) stated that the growing population and increase in trout fishing created new pressures on fish and game agencies to provide quality trout fishing. Considering the fact that overfishing was identified as a continued problem since the 1870s (MacDonald, 1884; New York Times, 1887; Surface, 1902; Osburn, 1923; Ingraham, 1926; Hewitt, 1931; Van Put, 1996), it is difficult to call this a 'new' pressure. Hunter (1991) even restated the old argument that hatchery trout are not capable of meeting these demands, and he repeated the belief that stream enhancement can provide an answer to the overfishing problem.

Currently, Monte Seehorn $(1985,1992)$ of the USFS provides two of the most widely referenced design manuals (i.e. Hunter, 1991; Brookes et al., 1996; Rosgen and Silvey, 1996). A review of the drawings reveals most of the familiar designs of dams, shelters and deflectors. The K-dam and wedge dam names and designs have not changed since the 1930s (Tarzwell, 1938; Gee, 1952; Seehorn, 1992). Seehorn's (1992) designs for log and brush shelters are similar to designs in the 1930s (Tarzwell, 1938) and later drawings in the 1960s (White and Brynildson, 1967). Seehorn's (1992) basic design for a deflector is almost identical to drawings produced in the 1930s (Tarzwell, 1938) and his recommendations for the deflection angle and the use of multiple deflectors to create a sinuous pattern date back to the 1920s (Mottram, 1928). Even recommendations for the combined use of deflectors and cover logs or paired deflectors (Seehorn, 1992) can be traced back to the 1930s (Hubbs et al., 1932; Tarzwell, 1938) and this practice was well established in the USFS by the 1950s (Gee, 1952). Therefore, it is difficult to see much progress in the techniques used relative to those recommended in publications decades earlier.

The modern design philosophy of Rosgen and Silvey (1996) also receives great attention at present (Hunter, 1991; National Research Council, 1992; Brookes and Shields, 1996a). Once again, this publication draws much of its information on the use of instream structures from older publications (White and Brynildson, 1967; Barton and Cron, 1979) that, in turn, were directly influenced by the works of Hewitt (1931) and Hubbs et al. (1932). Despite over 70 years of use of these types of habitat devices, authors still complain that there is little hydraulic design guidance available to help site instream structures (Shields et al., 1995). Ironically, the 1936 and 1969 USFS handbooks (Arthur, 1936; Cliff, 1969) provided much more detailed guidelines on the design of structures than subsequent publications (i.e. Hunter, 1991; Seehorn, 1992).

Modern publications continue to stress the lack of published evaluations of restoration projects (Kondolf and Micheli, 1995; Brookes and Shields, 1996b). However, the number of evaluations did dramatically increase in recent years relative to earlier periods. The National Research Council (1992) provided a good summary of some of the frequently-cited evaluations 
between the years 1968 and 1986. However, it should be noted that many projects continue to be evaluated with only one to two years of post-restoration data (i.e. House and Boehne, 1986; Olson and West, 1989; Shields et al., 1995; Van Zyll De Jong et al., 1997). The period from the late-1960s to the present also contains numerous accounts of failed restoration projects and detrimental impacts of instream structures (Babcock, 1986; Hamilton, 1989; Frissell and Nawa, 1992; Thompson, 2002). These facts resulted in a general call for the reformation of restoration practices by a number of researchers (National Research Council, 1992; Sear, 1994; Brookes, 1995; Kondolf and Downs, 1996; Haltiner et al., 1996; Gilvear, 1999; Thompson, 2002). However, it is clear that there is a great deal of tradition to overcome before reformation of practices is likely.

\section{DISCUSSION: CONTRADICTIONS IN THE USE OF INSTREAM STRUCTURES}

Perhaps some of the current mixed results regarding the use of instream structures stemmed from the lack of consensus on which techniques worked well in the past. For example, Thorne et al. (1997) recently suggested that deflectors can be angled upstream, downstream or parallel to the bank, but Hubbs et al. (1932) warn against using upstream and parallel angled deflectors as early as 1932 . Similarly, White and Brynildson (1967) argued against the use of peninsular-wing deflectors and peninsular-wing deflectors with chutes, and suggested only the use of triangular deflectors. However, more recent publications continued to recommend the use of peninsular-wing designs (Cliff, 1969; Barton and Cron, 1979; Thorne et al., 1997). Disagreements also exist in the types of building materials recommended. Madsen (1938) and Hamilton (1989) both claim rock is the most stable construction material. Conversely, Ehlers (1956) found that log dams and log deflectors were more stable than rock designs. Hewitt (1934) advised against the use of tarpaper and wire to prevent undermining, but Greeley (1935), Hunter (1991) and Seehorn (1992) all later proposed the use of these materials for this purpose. Similarly, the USFS and U.S. Department of Transportation suggested the use of gabions in 1969 and 1979 (Cliff, 1969; Barton and Cron, 1979) despite the fact that White and Brynlidson (1967) argued against these devices several years earlier.

Even basic watershed processes remain misunderstood. Forbes (1910) identified a clear link between flooding and food production in rivers, but Hewitt (1931) and Davis (1935) later forgot this fact and viewed floods as entirely destructive. The removal of LWD was identified as a problem in the 1920s and 1930s (Mottram, 1928; Hubbs et al., 1932), but Gee (1952) and White and Brynildson (1967) later advocated the removal of LWD and beaver dams because they presented migration barriers to fish. White and Brynildson (1967) even suggested that reforestation along trout streams should be discouraged. Meanwhile, over 80 years earlier, Van Cleef (1885) identified deforestation as one of the most serious impacts on fish habitat. Depending on which historic publications modern restoration designers rely upon, it is possible to reach very different conclusions on the relative suitability of a particular design or management practice. Therefore, it is not surprising that the experimental attitude adopted by restoration designers in the 1920s and 1930s persists today, with little change in the types of devices utilized to improve conditions in streams. It is also worth noting that no structural solution will ever truly solve the inherent problems in the ecosystem if overfishing is a main cause of population declines.

\section{CONCLUSIONS}

The modern use of instream structures in channel restoration follows a tradition that dates back more than 100 years in the U.S. Early restoration attempts focused on high-maintenance, short-lived and localized fixes to the problems of overfishing and land-use impacts. The designers valued select fish species above all other environmental concerns, and followed management practices that are considered environmentally damaging by today's standards. The goals of the projects were narrowly focused and failed to consider channel dynamics. The modern structural approach to the problem follows a similar philosophy with many of the same drawbacks. Although modern designers have often recognized the dynamic nature of rivers, they continue to use static designs that impose an affect on the river. A review of the literature shows that the tradition of using instream structures became established long before comprehensive evaluations of the effect of habitatenhancement devices on fish production were completed. Although many failed restoration projects are reported and limitations in the use of stream-improvement devices are obvious, structures continue to be used because of the perception that they have clear benefits for target species of aquatic organisms. However, many researchers have concluded that instream structures do more harm than good, even for the target species they are designed to aid. Given the doubts surrounding the successful use of instream structures to improve aquatic populations, it is time to abandon the practices of the past and adopt a more scientific basis for channel-restoration design. This new approach should focus on replicating natural processes and patterns to the greatest degree possible based on research that demonstrates how natural channel morphologies form and function. Ultimately, a successful restoration program should treat the underlying cause of the problems, overfishing and land-use impacts, not the symptoms of reduced fishing catches.

\section{ACKNOWLEDGEMENTS}

Patrice Brodeur, Geoffrey Atherton, Nicole Carette and Luce Venne-Forcione provided translations for the abstract and figure captions. Rebecca Nash, James Nash, Mike Miles and one anonymous reviewer graciously agreed to review draft versions of the manuscript. Jaime Goode, Melanie Gryboski and Lauren Hartzell provided assistance with the literature review.

\section{REFERENCES}

Aitken, W.W., 1935. lowa stream improvement work. Transactions of the American Fisheries Society, 65: 322-333.

Anonymous, 1876. The fish way. Scientific American, 35: 275. 1906. About Kingfishers. Forest and Stream, 67: 338. 
Armistead, W.H., 1920. Trout Waters: Management and Angling. A\&C Black Ltd., London, 195 p.

Arthur, M.B., 1936. Fish Stream Improvement Handbook. U.S. Forest Service, Washington, D.C., $33 \mathrm{p}$.

Babcock, W.H., 1986. Tenmile Creek: A study of stream relocation. Water Resources Bulletin, 22: 405-415.

Barton, J.R. and Cron, F.W., 1979. Restoration of Fish Habitat in Relocated Streams. U.S. Department of Transportation, Federal Highway Administration, FHWA-IP-79-3, Washington, D.C., 63 p.

Brookes, A., 1995. Challenges and objectives for geomorphology in U.K. river management. Earth Surface Processes and Landforms, 20: 593-610.

Brookes, A., Knight, S.S. and Shields, F.D., 1996. Habitat enhancement, p. 103126. In A. Brookes and F.D. Shields, eds., River Channel Restoration: Guiding Principles for Sustainable Projects. John Wiley, London, $433 \mathrm{p}$.

Brookes, A. and Shields, F.D., eds., 1996a. River Channel Restoration: Guiding Principles for Sustainable Projects. John Wiley, London, $433 \mathrm{p}$.

1996b. Perspectives on river channel restoration, p. 1-19. In A. Brookes and F.D. Shields, eds., River Channel Restoration: Guiding Principles for Sustainable Projects. John Wiley, London, $433 \mathrm{p}$.

Burger, H., 1932. The partnership of wood and water. American Forests, 38: 197-201.

Cheney, A.N., 1900. A natural hatchery for trout. Forest and Stream, 54: 70.

Cliff, E.P., 1969. Wildlife Habitat Improvement Handbook. U.S. Forest Service, FSH 2609.11, Washington, D.C., 146 p.

Cooper, C.M. and Knight, S.S., 1987. Fisheries in man-made pools below gradecontrol structures and in naturally occurring scour holes of unstable streams. Journal of Soil and Water Conservation, 42: 370-373.

Cumings, E.M., 1932. Better trout fishing. Outdoor America, 10: 26-31.

Davis, H.S., 1935. The purpose and value of stream improvement. Transactions of the American Fisheries Society, 64: 63-67.

Ehlers, R., 1956. An evaluation of stream improvement devices constructed eighteen years ago. California Fish and Game, 42: 203-217.

Emerson, J.W., 1971. Channelization: A case study. Science, 173: 325-326.

Feast, C.N., Jr., 1938. Stream improvement and fish planting plans in the National Forests of the Central Rocky Mountain Region. Transactions of the Third North American Wildlife Conference (Baltimore, Maryland), 3: 428-432.

Fechner, R., 1936. Memorandum for the Press: November 29, 1936. Emergency Conservation Work, E.C.W. 127211, Washington, D.C.,8 p.

Forbes, S.A., 1910. The investigation of a river system in the interest of its fisheries. Transactions of the American Fisheries Society, 40: 179-193.

Frissell, C.A. and Nawa, R.K., 1992. Incidence and causes of physical failure of artificial habitat structures in streams of western Oregon and Washington. North American Journal of Fisheries Management, 12: 182-197.

Gee, M.A., 1952. Stream Improvement Handbook. U.S. Forest Service, Washington, D.C., 21 p.

Gilbert, M., 1881. Shaw's Fishway. Forest and Stream, 16: 411.

Gilvear, D.J., 1999. Fluvial geomorphology and river engineering: future roles utilizing a fluvial hydrosystems framework. Geomorphology, 31: 229-245.

Greeley, J.R., 1935. Progress of stream improvement in New York State. Transactions of the American Fisheries Society, 65: 316-322.

Greeley, J.R. and Tarzwell, C.M., 1932. How Michigan is making better trout streams. American Forests, 38: 460-480.

Haltiner, J.P., Kondolf, G.M. and Williams, P.B., 1996. Restoration approaches in California, p. 291329. In A. Brookes and F.D. Shields, eds., River Channel Restoration: Guiding Principles for Sustainable Projects. John Wiley, London, $433 \mathrm{p}$.

Hamilton, J.B., 1989. Response of juvenile Steelhead to instream deflectors in a high gradient stream, p. 149-158. In R.E. Gresswell, B.A. Barton and J.L. Kershner, eds., Practical Approaches to Riparian Resource Management: An Educational Workshop. U.S. Bureau of Land Management, Billings, $193 \mathrm{p}$.
Hazzard, A.S., 1937. Results of stream improvement work in Michigan Transactions of the Second North American Wildlife Conference (Washington, D.C.), 2: 620-624.

Heins, D.C. and Matthews, W.J., 1987. Historical perspectives on the study of community and evolutionary ecology of North American stream fishes, p. 3-7. In W.J. Matthews and D.C. Heins, eds., Community and Evolutionary Ecology of North American Fishes. University of Oklahoma Press, Norman, $310 \mathrm{p}$.

Henshall, J.A., 1906. Fish and irrigation ditches. Forest and Stream, 67: 338.

Hewitt, E.R., 1931. Better Trout Streams: Their Maintenance with Special Reference to Trout Habits and Food Supply, Charles Scribner's Sons, New York, $140 \mathrm{p}$.

1934. Hewitt's Handbook of Stream Improvement, The Marchbanks Press, New York, 82 p.

House, R.A. and Boehne, P.L., 1986. Effects of instream structures on salmonid habitat and populations in Tobe Creek, Oregon. North American Journal of Fisheries Management, 6: 38-46.

Hubbs, C.L., 1931. Fisheries research in Michigan. Transactions of the American Fisheries Society, 60: 182-186.

1932. The improvement of trout streams. American Forests, 38: 394-431.

1937. Fish management: Looking forward. Transactions of the American Fisheries Society, 66: 51-55.

Hubbs, C.L, Greeley, J.R. and Tarzwell, C.M., 1932. Methods for the improvement of Michigan trout streams. Institute for Fisheries Research. Bulletin of the Institute for Fisheries Research, 1, University of Michigan Press, Ann Arbor, $54 \mathrm{p}$.

Hubbs, C.L., Tarzwell, C.M. and Eschmeyer, R.W., 1933. C.C.C. stream improvement work in Michigan. Transactions of the American Fisheries Society, 63: 404-414.

Hunt, R.L., 1976. A long-term evaluation of trout habitat development and its relation to improving management-related research. Transactions of the American Fisheries Society, 105: 361-364.

Hunter, C.J., 1991. Better Trout Habitat, Island Press, Washington, D.C., 320 p.

Hunter, G.W., III, Thorpe, L.M. and Grosvenor, D.E., 1941. An attempt to evaluate the effects of stream improvement in Connecticut. Transactions of the Fifth North American Wildlife Conference (Washington, D.C.), 5: 276-291

Ingraham, H.A., 1926. American Trout Streams, The Anglers' Club of New York, New York, $139 \mathrm{p}$.

Iversen, T.M., Kronvang, B., Madsen, B.L., Markmann, P. and Nielsen, M.B. 1993. Re-establishment of Danish streams: Restoration and maintenance measures. Aquatic Conservation: Marine and Freshwater Ecosystems, 3: 73-92.

Keller, E.A., 1975. Channelization: A search for a better way. Geology, 86: 246-248.

Keller, E.A. and Swanson, F.J., 1979. Effects of large organic material on channel form and fluvial processes. Earth Surface Processes, 4: 361-380.

Kondolf, G.M., 1995. Five elements for effective evaluation of stream restoration. Restoration Ecology, 3: 133-136.

Kondolf, G.M. and Downs, P.W., 1996. Catchment approach to planning channel restoration, p. 129-148. In A. Brookes and F.D. Shields, eds., River Channel Restoration: Guiding Principles for Sustainable Projects. John Wiley, London, $433 \mathrm{p}$.

Kondolf, G.M. and Micheli, E.R., 1995. Evaluating stream restoration projects. Environmental Management, 19: 1-15.

Kylie, H.R., Hieronymus, G.H. and Hall, A.G., 1937. CCC Forestry. Office of Education, Washington, D.C., 218 p.

Leach, G.C., 1919. Culture of Rainbow Trout and Brook Trout in Ponds. Department of Commerce, Bureau of Fisheries, Economic Circular, 41, Washington, D.C., $19 \mathrm{p}$.

Leonard, J.W., 1940. Some comments on stream improvement in Michigan Michigan Conservation, 10: 6, 7, 10. 
Leopold, L.B., Wolman, M.G. and Miller, J.P., 1964. Fluvial Processes in Geomorphology, Dover Publications, New York, 522 p.

Lord, R.F., 1935. The 1935 trout harvest from Furnace Brook, Vermont's "Test Stream". Transactions of the American Fisheries Society, 65: 224-233.

MacDonald, M., 1883. The Columbia Dam fishway. Forest and Stream, 21: 330. 1884. A new system of fishway-building. Forest and Stream, 21: 457-458.

Madsen, M.J., 1938. A preliminary investigation into the results of stream improvement in the intermountain forest region. Transactions of the Third North American Wildlife Conference (Baltimore, Maryland), 3: 497-503

Meehan, W.E., 1905. Pennsylvania Fisheries Department. Forest and Stream, 64: 159.

Mottram, J.C., 1928. Trout Fisheries: Their Care and Preservation, Herbert Jenkins, London, $186 \mathrm{p}$

Muhar, S., 1996. Habitat improvement of Austrian rivers with regard to different scales. Regulated Rivers: Research and Management, 12: 471-482.

National Research Council, 1992. Restoration of Aquatic Ecosystems: Science, Technology and Public Policy. National Academy Press, Washington, D.C., $552 \mathrm{p}$.

New York Times, 1887. Fish and Protection. Forest and Stream, 29: 168.

Norton, S.N., 1880. The McCloud River Dam. Forest and Stream, 14: 146.

Nunnally, N.R., 1978. Stream renovation: An alternative to channelization. Environmental Management, 2: 403-411.

Olson, A.D. and West, J.R., 1989. Evaluation of instream fish habitat restoration structures in Kalamath River tributaries, 1988/1989. U.S. Forest Service, Annual Report for Interagency Agreement, 14-16-0001-09608, Treka, 36 p.

Osburn, R.C., 1923. Natural and artificial conditions detrimental to the black bass. Transactions of the American Fisheries Society, 53: 27-40.

Otis, M.B., 1974. Stream improvement, p. 99-122 In J.M. Migel, ed., The Stream Conservation Handbook. Crown Publishers, New York, 242 p.

Parry, E.A., 1932. And I in Arcadia. American Forests, 38: 326-328.

Richardson, E.V., Simons, D.B. and Julien, P.Y., 1990. Highways in the River Environment. U.S. Department of Transportation, Federal Highway Administration, McLean, $555 \mathrm{p}$.

Riley, A.L., 1998. Restoring Streams in Cities, Island Press, Washington, D.C. $423 \mathrm{p}$.

Rogers, W.H., 1888. The Rogers fishway. Forest and Stream, 29: 506-508.

Rosgen, D. and Silvey, H.L., 1996. Applied River Morphology, Wildland Hydrology, Pagosa Springs, $380 \mathrm{p}$.

Saunders, J.W. and Smith, M.W., 1962. Physical alteration of stream habitat to improve brook trout production. Transactions of the American Fisheries Society, 82: 185-188.

Schley, B., 1971. A Century of Fish Conservation. U.S. Fish and Wildlife Service, Washington, D.C., 4 p.
Sear, D.A., 1994. River restoration and geomorphology. Aquatic Conservation: Marine and Freshwater Ecosystems, 4: 169-177.

Seehorn, M.E., 1985. Fish Habitat Improvement Handbook. U.S. Forest Service Southern Region, Technical Publication, R8-TP 7, Atlanta, 30 p.

1992. Stream Habitat Improvement Handbook. U.S. Forest Service, Southern Region, Technical Publication, R8-TP 16, Atlanta, 30 p.

Shetter, D.S., Clark, O.H. and Hazzard, A.S., 1946. The effects of deflectors in a section of a Michigan trout stream. Transactions of the American Fisheries Society, 76: 248-278.

Shields, F.D., Cooper, C.M. and Knight, S.S., 1995. Experiment in stream restoration. Journal of Hydraulic Engineering, 121: 494-502.

Surface, H.A., 1902. Natural preservation of fishes. Forest and Stream, 59: 374

Swales, S., and O'Hara, K., 1980. Instream habitat devices and their use in freshwater fisheries management. Journal of Environmental Management, 10: 167-179.

Tarzwell, C.M., 1935. Progress in lake and stream improvement. Transactions of the Twenty-first American Games Conference, 21: 119-134.

1936. Experimental evidence of the value of trout stream improvements. Transactions of the American Fisheries Society, 66: 177-187.

1938. An evaluation of the methods and results of stream improvement in the Southwest. Transactions of the Third North American Wildlife Conference (Baltimore, Maryland), 3: 339-364.

Thompson, D.M., 2002. Long-term effect of instream habitat-improvement structures on channel morphology along the Blackledge and Salmon Rivers, Connecticut, USA. Environmental Management, 29: 250-265.

Thorne, C.R., Hey, H.D. and Newson, M.D., 1997. Applied Fluvial Geomorphology for River Engineering and Management, John Wiley, New York, $376 \mathrm{p}$.

Trexler, H.C., 1897. Pennsylvania Commission. Forest and Stream, 49: 250

Van Cleef J.S., 1885. How to restore our trout streams. Transactions of the American Fisheries Society, 14: 50-55.

Van Put, E., 1996. The Beaverkill: The History of a River and Its People, Lyons \& Burford, New York, $298 \mathrm{p}$.

Van Zyll De Jong, M.C., Cowx, I.G. and Scruton, D.A., 1997. An evaluation of instream habitat restoration techniques on salmonid populations in a Newfoundland stream. Regulated Rivers: Research and Management, 13: 603-614.

Wheeler, R., 1888. Buffalo Creek. Forest and Stream, 30: 293.

White, R.J. and Brynildson, O.M., 1967. Guidelines for Management of Trout Stream Habitat in Wisconsin, Department of Natural Resources, Technical Bulletin 39, Madison, $66 \mathrm{p}$.

Williams, G.P. and Wolman, M.G., 1985. Effects of dams and reservoirs on surface-water hydrology: Changes in rivers downstream from dams, p. 83-88. In National Water Summary 1985, U.S. Geological Survey Water Supply Paper, 1985, Washington, D.C., 391 p.

Y, X., 1887. Save the streams. Forest and Stream, 29: 49. 